ISSN: 2224-0616

Int. J . Agril. Res. Innov. \& Tech. 5(2): 21-30, December, 2015

Available online at http:// www.ijarit.webs.com

\title{
SOIL LOSS ESTIMATION USING GEOGRAPHIC INFORMATION SYSTEM IN ENFRAZ WATERSHED FOR SOIL CONSERVATION PLANNING IN HIGHLANDS OF ETHIOPIA
}

\author{
Gizachew Tiruneh ${ }^{*}$ and Mersha Ayalew ${ }^{2}$
}

Received 4 August 2015, Revised 15 November 2015, Accepted 22 December 2015, Published online 31 December 2015

\begin{abstract}
Accelerated soil erosion is a worldwide problem because of its economic and environmental impacts. Enfraz watershed is one of the most erosion-prone watersheds in the highlands of Ethiopia, which received little attention. This study was, therefore, carried out to spatially predict the soil loss rate of the watershed with a Geographic Information System (GIS) and Remote Sensing (RS). Revised Universal Soil Loss Equation (RUSLE) adapted to Ethiopian conditions was used to estimate potential soil losses by utilizing information on rainfall erosivity (R) using interpolation of rainfall data, soil erodibility (K) using soil map, vegetation cover (C) using satellite images, topography (LS) using Digital Elevation Model (DEM) and conservation practices (P ) using satellite images. Based on the analysis, about 92.31\% (5914.34 ha) of the watershed was categorized none to slight class which under soil loss tolerance (SLT) values ranging from 5 to 11 tons ha-1 year ${ }^{-1}$. The remaining $7.68 \%$ (492.21 ha) of land was classified under moderate to high class about several times the maximum tolerable soil loss. The total and an average amount of soil loss estimated by RUSLE from the watershed was 30,836.41 ton year ${ }^{1}$ and 4.81 tons ha- ${ }^{-1} y e a r^{1}$, respectively.
\end{abstract}

Keywords: Enfraz Watershed, Ethiopia, GIS, RUSLE, Soil Erosion

${ }^{1}$ Faculty of Agriculture and Environmental Sciences, Debre Tabor University, Debre Tabor, Ethiopia

${ }^{2}$ Amhara Design and Supervision Works Enterprise, Bahir Dar, Ethiopia

*Corresponding author's email: gizachewayalew75@yahoo.com (Gizachew Tiruneh)

\section{Introduction}

Soil erosion is one of the biggest global environmental hazards causing severe land degradation. Population explosion, deforestation, unsustainable agricultural cultivation, and overgrazing are among the main factors causing soil erosion hazards. In the Ethiopian highlands, an annual soil loss reaches 200-300 tons ha-1 year ${ }^{1}$ (FAO, 1984; Hurni, 1993). It has been estimated that out of the estimated 60 million ha of agriculturally productive land, about 27 million ha are significantly eroded, 14 million ha are seriously eroded and 2 million ha have reached the point of no return, with an estimated total loss of 2 billion cubic meters of top soil per annum (Fikru, 1990). The average crop yield from a piece of land in Ethiopia is very low mainly due to soil fertility decline associated with removal of topsoil by erosion (Sertu, 2000).

There have been rare studies carried out to quantify erosion rates in Enfranz watershed. In addition, the soil loss estimated by different researchers varied for the watershed. This implies that there is a need to have watershed specific information on soil erosion to support timely information for decision makers and land managers that plan the correct soil conservation planning. As different portions of the landscape vary in sensitivity to erosion through differences in their slope, soil and land use and cover attributes, it was necessary to estimate rates of soil loss and develop a soil loss intensity map of the study watershed using RUSLE within a GIS environment, identify severity areas and prioritize areas for specific soil conservation plans.

\section{Materials and Methods}

\section{Description of the study watershed}

Geographically Enfranz Watershed is located between 1275696.98 to $1285116.61 \mathrm{~m}$ North and 304319.37 to $316257.13 \mathrm{~m}$ East with an altitude ranging of 1813 to 2006 m.a.s.l. and total area of 6423.56 ha (Fig. 1). The watershed's temperature ranges from 17.5 to $20.0^{\circ} \mathrm{C}$ (tepid thermal zone) and the mean annual rainfall varies from 1200 $1500 \mathrm{~mm}$. 


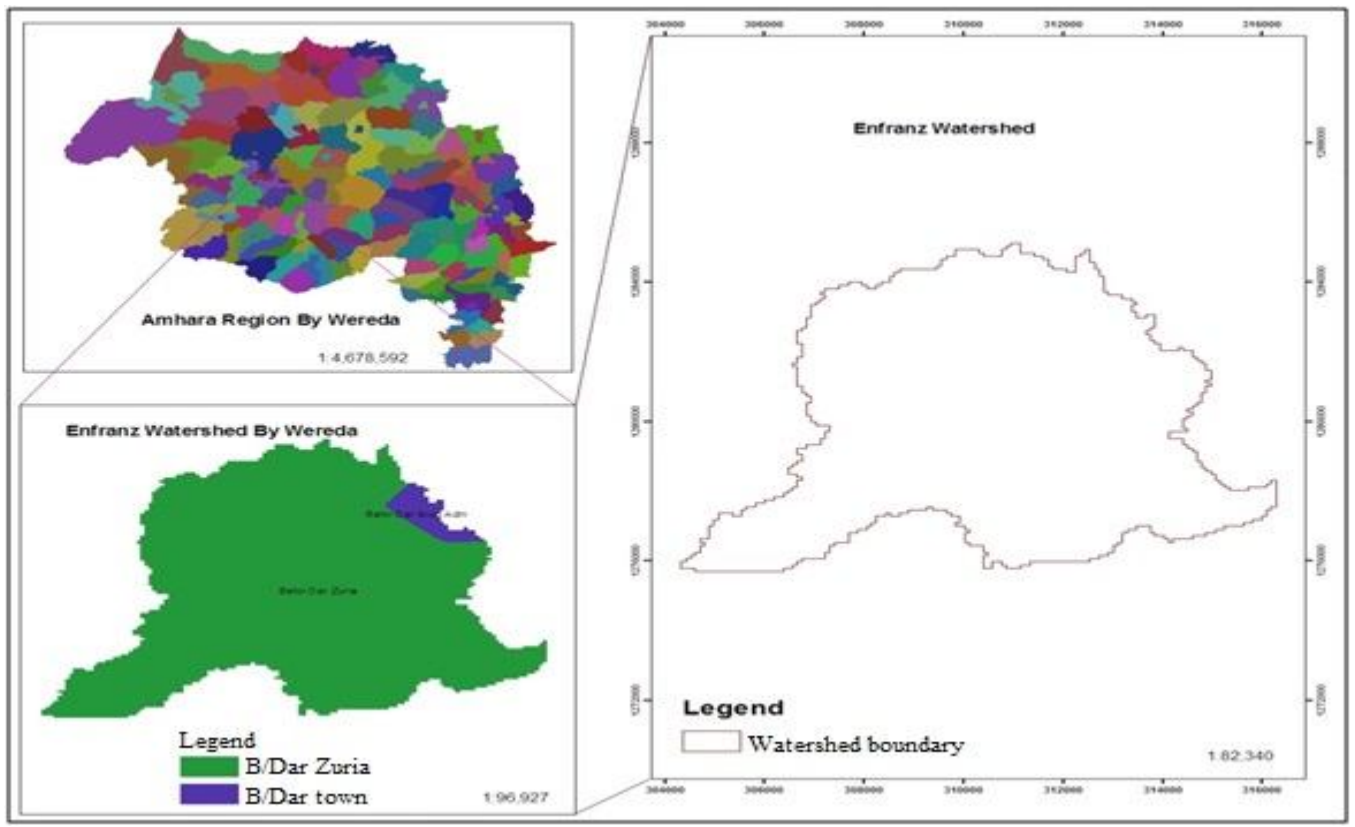

Fig. 1. Location map of Enfranz watershed

The input thematic data included rainfall, soil units, slopes and land use/ cover was determined as follow:

\section{Rainfall erosivity factor}

The monthly amounts of rainfall for the watershed were collected over 15 years by the Amhara Regional Meteorological Agency. Monthly rainfall records from these meteorological stations covering the period 19982012 were used to calculate the rainfall erosivity Factor (R-value). The mean annual rainfall was first interpolated to generate continuous rainfall data for each grid cell by "3D Analyst Tools Raster Kriging Interpolation" in ArcGIS. Then, the R-value corresponds to the mean annual rainfall of the watershed was found using the $\mathrm{R}$ correlation established in Hurni (1985) from a spatial regression analysis (Hellden, 1987) for Ethiopian conditions to Ethiopia condition.

$\mathrm{R}=8.12+0.562 \mathrm{P}$

Equation (1)

Where $\mathrm{R}$ is the rainfall erosivity factor and $\mathrm{P}$ is the mean annual rainfall ( $\mathrm{mm}$ ).

\section{Soil erodibility factor}

"Spatial Analyst Tool Extract by Mask" in GIS was used to obtain soil units map of the watershed from Amhara Regional digital soil map at 1:50,000 scale (DSA and SCI, 2006). The soil erodibility (K) factor was estimated based on soil unit types (FAO, 1989; Hurni, 1985; Hellden, 1987). The resulting shape file was changed to raster with a cell size of $30 \mathrm{~m}$ x $30 \mathrm{~m}$. The raster map was reclassified based on their erodibility value.

\section{Slope length and slope steepness}

The $30 \mathrm{~m}$ spatial resolution DEM (digital elevation model) was used to generate slope as shown in Fig. 2 by using "Spatial Analyst Tool Surface Slope" in ArcGIS 10.1 environment. The flow accumulation and slope steepness were computed from the DEM using ArcGIS. Flow accumulation and slope maps were multiplied by using "Spatial Analyst Tool Map Algebra Raster Calculator" in Arc GIS 10.1 environment to calculate and map the slope length (LS factor) as shown in Equation 2 and 3.

$$
\begin{array}{ll}
\mathrm{L}=0.799+0.0101 * \text { Flow Accumulation } & \text { Equation (2) } \\
\mathrm{S}=0.344+0.0798 * \text { Slope } & \text { Equation (3) }
\end{array}
$$

Where, L and S stand for slope length and steepness factor

\section{Land use/cover data and crop management factor}

A land-use and land-cover map of the study area was prepared from LANDSAT satellite image acquired on 2014 and supervised digital image classification technique was employed using ENVI 5.0 software. A field checking effort also was made to collect ground truth information. The LAND SAT satellite image was used to classify the current land use and land cover map. Digital image processing operations were carried out using ENVI 5.0 software.

In addition, ground truth data were used as a vital reference for supervised classification, accuracy assessment and validation of the result. In supervised image classifications technique, land use and land cover types were classified to 
use the classified images as inputs for generating crop management (C) factor and support practice (P) factor. Based on the land cover classification map, a corresponding $\mathrm{C}$ value was obtained from Hurni (1985) and assigned in a GIS.

\section{Erosion management practice factor}

The P-factor was assessed using major land cover and slope interaction adopted by Hurni (1985) for Ethiopia condition. The data related to management or support practices of the watershed were collected during the fieldwork. Therefore, values for this factor were assigned considering local management practices and it was taken the weighed value for similar land use types. The corresponding $P$ values were assigned to each land use/land cover classes and slope classes and the $\mathrm{P}$ factor map was produced.

\section{Soil loss analysis}

The overall methodology involved the use of the RUSLE in a GIS environment with factors obtained from meteorological stations, soil map, topographic map, Satellite Images and DEM as shown in Fig. 2. Annual soil loss rate was determined by a cell-by-cell analysis of the soil loss surface by superimposing and multiplying the respective RUSLE factor values (R, K, LS, C and P) interactively by using "Spatial Analyst Tool Map Algebra Raster Calculator" in ArcGIS 10.1 environment as shown Equation 4 (Hurni, 1985; Gebreselasie, 1996).

For the purpose of identifying priority areas for conservation planning, soil loss potential of the study area was first categorized into different severity classes following FAO's basis of classification (FAO and UNEP, 1984).

$\mathrm{A}=\mathrm{LS}^{*} \mathrm{R}^{*} \mathrm{~K}^{*} \mathrm{C}^{*} \mathrm{P}$

Equation (4)

Where A is the annual soil loss (metric tons ha-1 year ${ }^{1}$ ); $\mathrm{R}$ is the rainfall erosivity factor [MJ $\mathrm{mm}$ $\mathrm{h}^{-1} \mathrm{ha}^{-1}$ year ${ }^{-1}$; $\mathrm{K}$ is soil erodibility factor [metric tons ha-1 $\mathrm{MJ}^{-1} \mathrm{~mm}^{-1}$; LS = slope length factor (dimensionless); $\mathrm{C}$ is land cover and management factor (dimensionless); and $\mathrm{P}$ is conservation practice factor (dimensionless). Ground truth data selected across land covers and collected by GPS were used for checking and validation of results (Fig. 2 and 3).

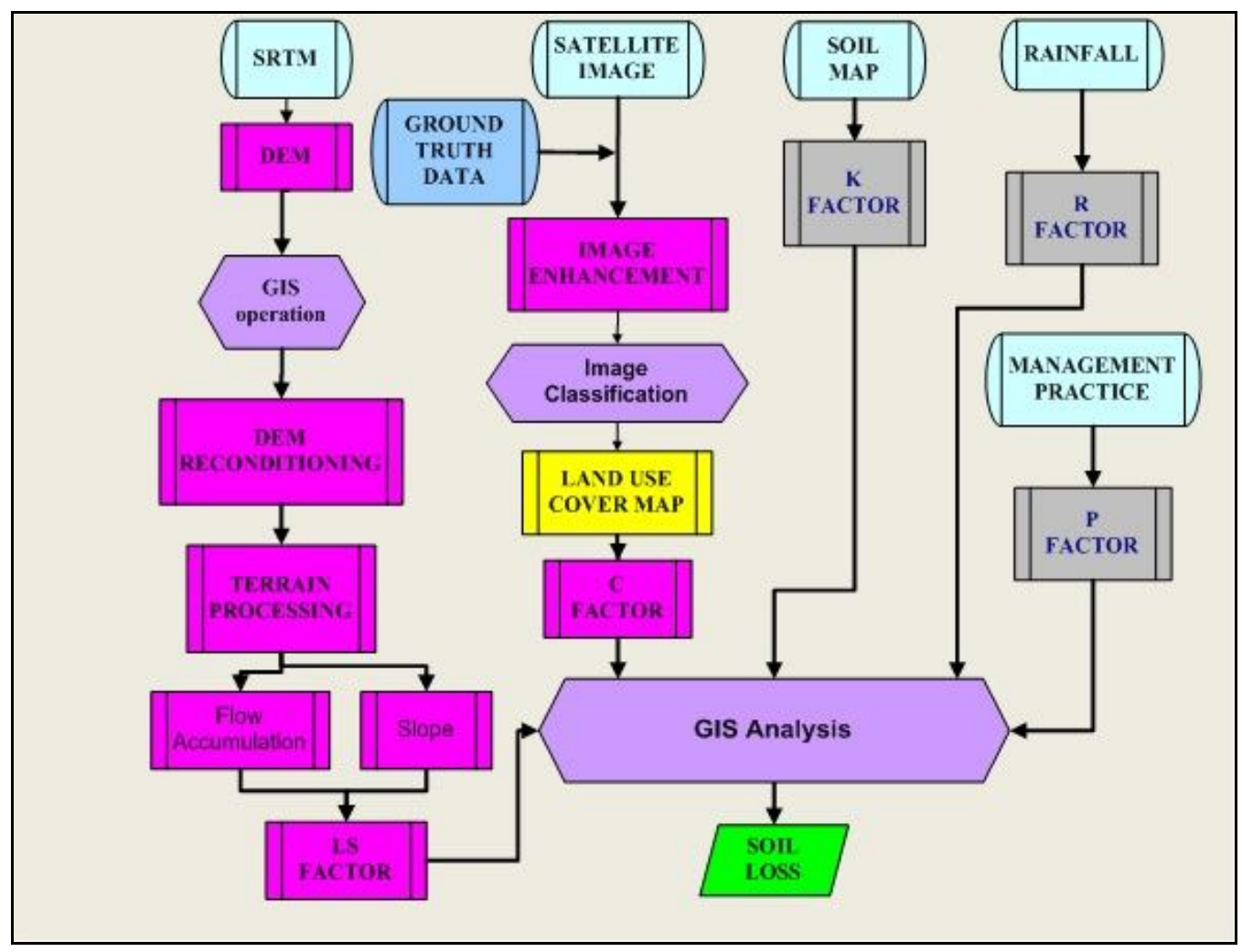

Fig. 2. Procedures of RUSLE implementation in GIS 


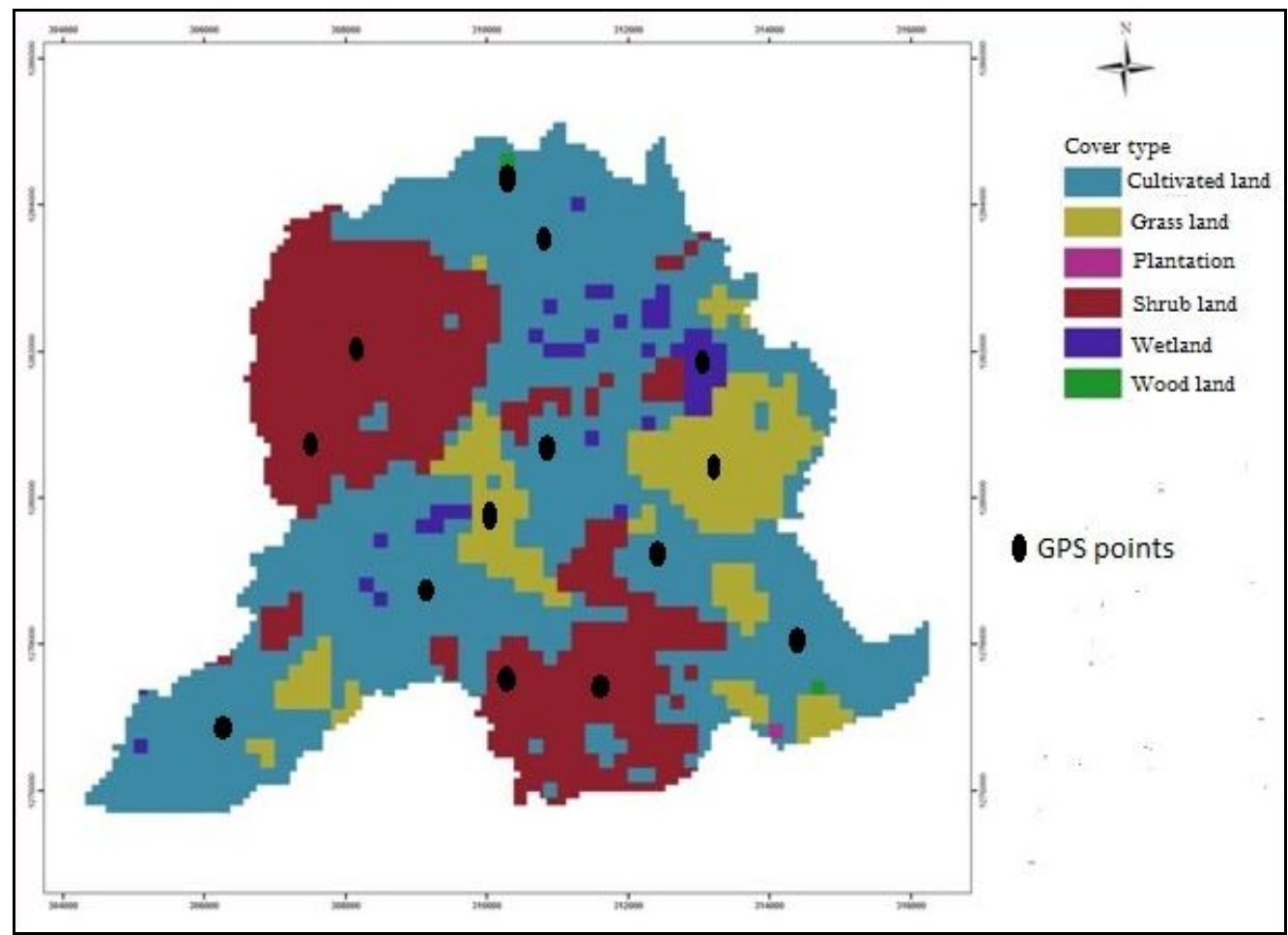

Fig. 3. GPS points used to validate against for spatial soil loss estimation

\section{Results and Discussion}

\section{Rainfall erosivity factor (R)}

Soil loss is closely related to rainfall partly through the detaching power of raindrops striking the soil surface and partly through the contribution of rain to runoff (Morgan, 1994). The annual rainfall of the watershed is ranging $1350 \mathrm{~mm}$. The result showed that the average Rfactor value in the watershed was 750.58 MJ mmha ${ }^{-1}$ year $^{-1}$.

\section{Soil erodibility factor (K)}

The erodibility of a soil is an expression of its inherent resistance to particle detachment and transport by rainfall. It is determined by the cohesive force between the soil particles, and may vary depending on the presence or absence of plant cover, the soil's water content and the development of its structure.

The soil erodibility factor (K) represents the effect of soil properties and soil profile characteristics on soil loss (Renard et al., 1997). Erodibility depends essentially on the amount of organic matter in the soil, the texture of the soil, the structure of the surface horizon and permeability (Robert and Hilborn, 2000). The results indicated that soil erodibility value in the study watershed ranged from $0.15 \mathrm{Mgh} \mathrm{MJ}^{-1}$ $\mathrm{mm}^{-1}$ to $0.20 \mathrm{Mgh} \mathrm{MJ}^{-1} \mathrm{~mm}^{-1}$ (Fig. 3). 


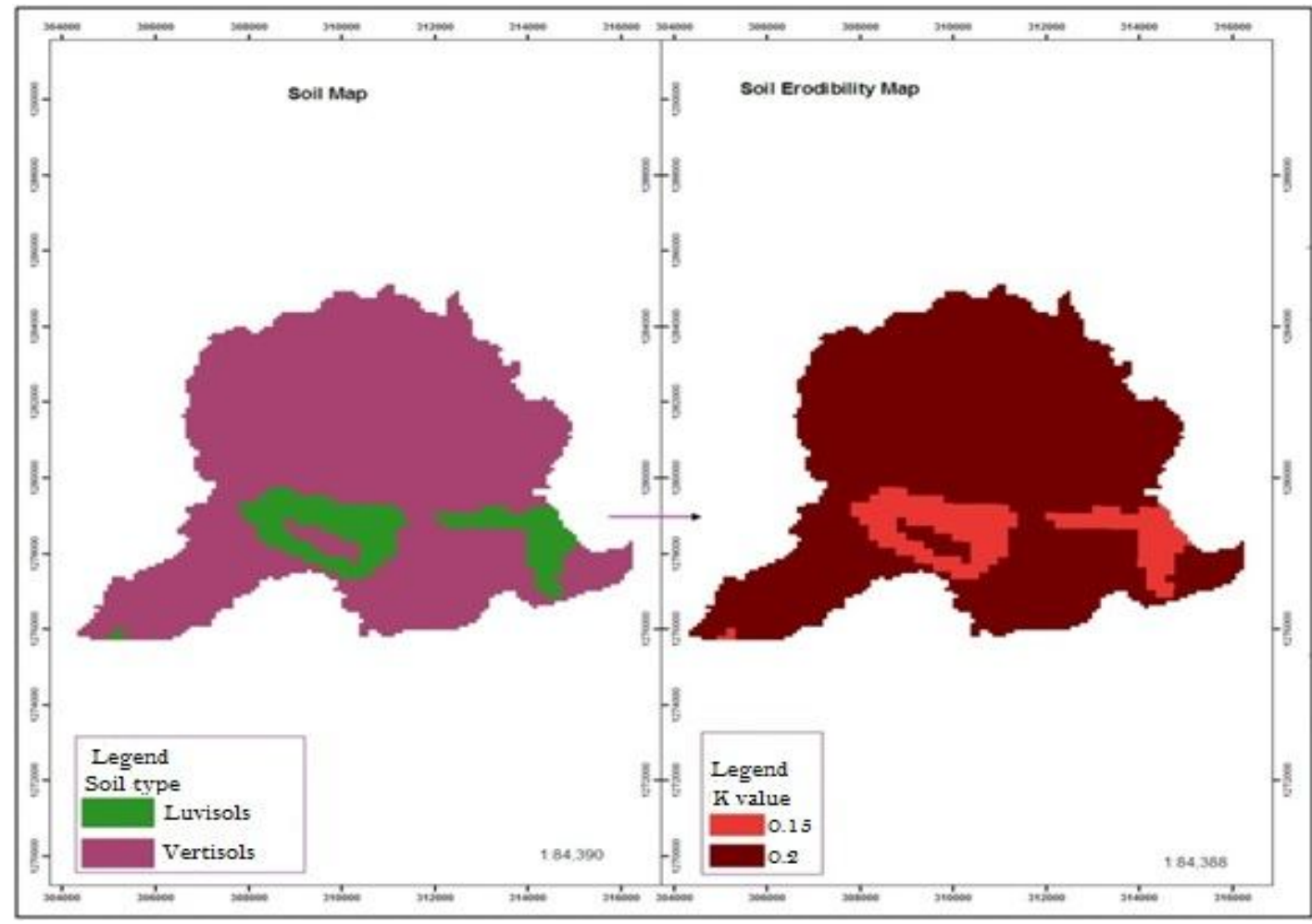

Fig. 4. Derivation of soil erodibility value from soil data

\section{Slope length and slope steepness factor Slope length (L)}

The slope length and gradient factors was estimated from Digital Elevation Model (DEM) data in the GIS environment. The technique described here for computing $L$ requires a flow accumulation grid layer. The flow accumulation also was computed from DEM. The cell size of the DEM represents the length of the cell. As shown in Fig. 4, the slope length was ranged from 0.8 to $75.38 \mathrm{~m}$.

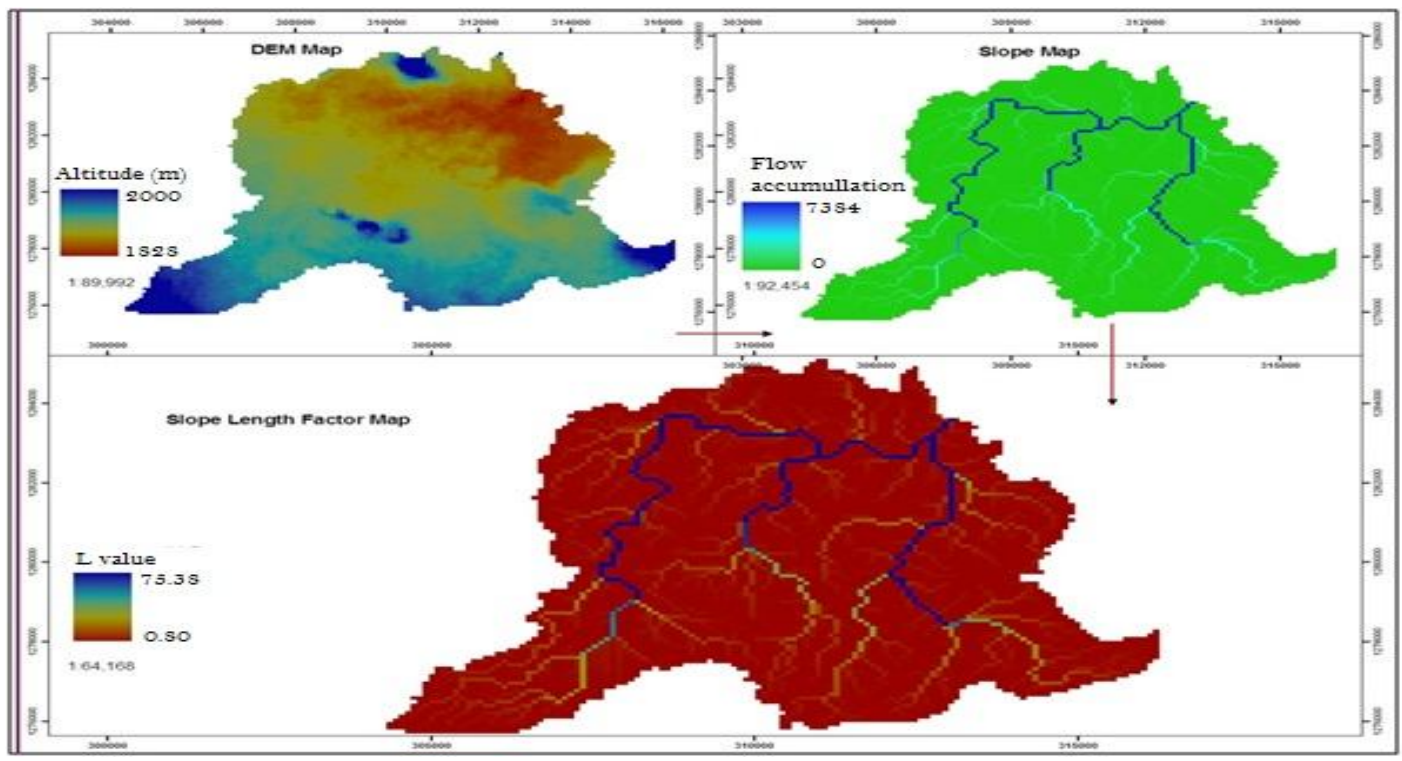

Fig. 5. Model for slope length factor derivation from flow accumulation and slope data 


\section{Steepness Factor (S)}

As the slope steepness and slope grid layer increases, the velocity and erosivity of runoff increase in the down slope direction. The slope steepness factor estimated from DEM data in the GIS as slope grid layer. Fig. 5 showed the steepness factor was ranged from 0.344 to 4.29 .

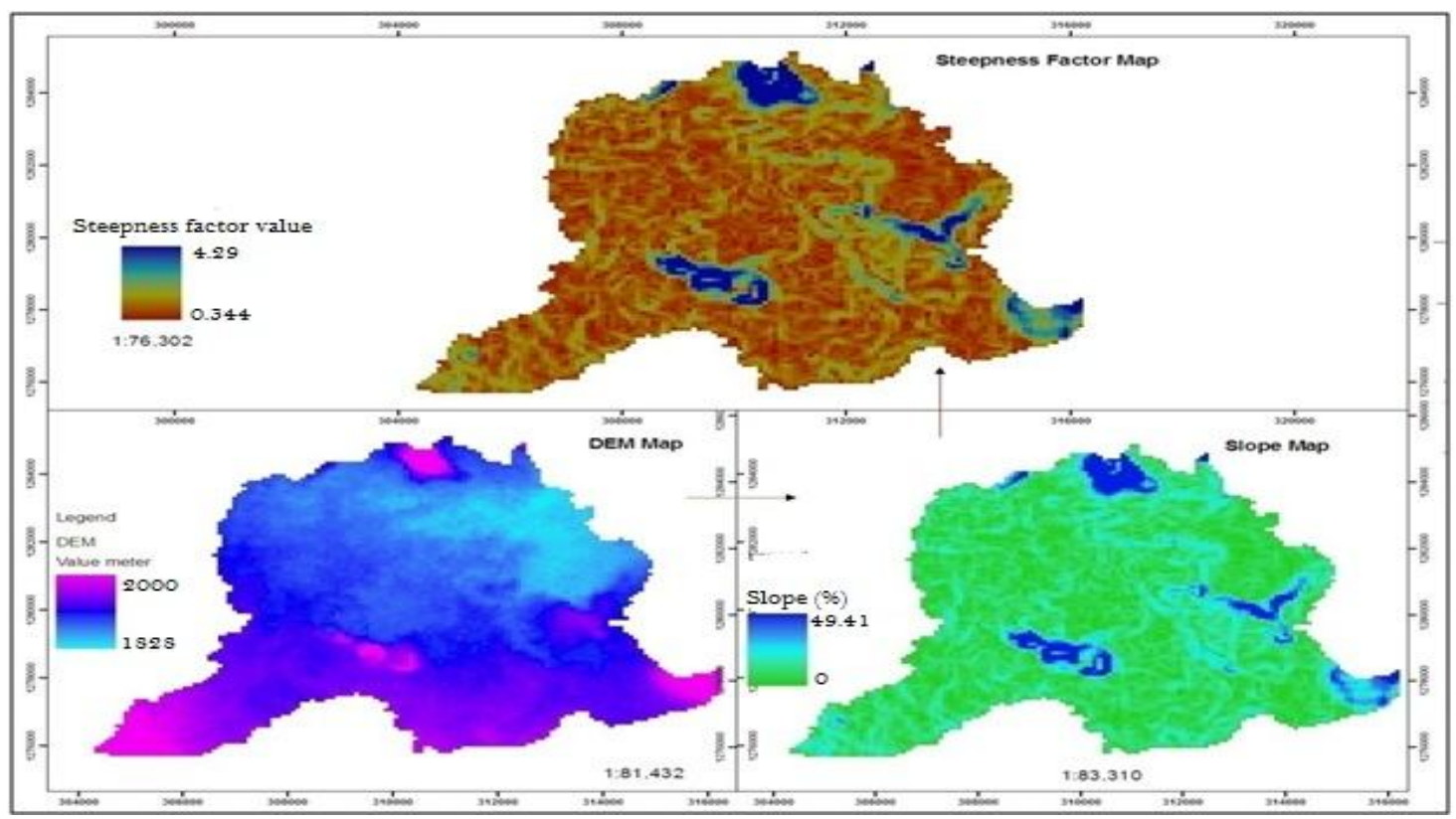

Fig. 6. Derivation of steepness factor from slope map

\section{Land use and land cover and crop factor (C)}

The cover management factor $(\mathrm{C})$ represents the ratio of soil loss under a given crop to that of the base soil (Morgan, 1994). The C- value measures the combined effect of cropping and management practices in agricultural system and the effect of ground cover, tree canopy and grass covers in reducing soil loss in non-agricultural condition. It also reflects the effect of cropping and management practices on the soil erosion rate (Renard et al., 1997). Table 1 and Fig. 6 indicated that six land-use and land-cover classes were recognized in the watershed, dominantly by cultivated land (55.55\%) and shrub (28.80\%). Crop management $\mathrm{C}$ factor values of the study watershed were ranging from 0.01 to 0.35 and it was similar with the work of Morgan (2005).

Table 1. Cover management (C) factor values of the study area

\begin{tabular}{clccc}
\hline \multirow{2}{*}{ No. } & Land Cover & \multicolumn{2}{c}{ Area coverage } & Cover factor (C) \\
\cline { 3 - 4 } & & Hectare & Percent & \\
\hline 1 & Shrub & 1849.99 & 28.80 & 0.20 \\
2 & Grass & 811.77 & 12.64 & 0.05 \\
3 & Cultivated land & 3568.50 & 55.55 & 0.15 \\
4 & Wood Land & 12.00 & 0.19 & 0.01 \\
5 & Plantation forest & 3.96 & 0.06 & 0.01 \\
6 & Wet Land & 177.33 & 2.76 & 0.35 \\
\hline & Total & 6423.55 & 100 & \\
\hline
\end{tabular}




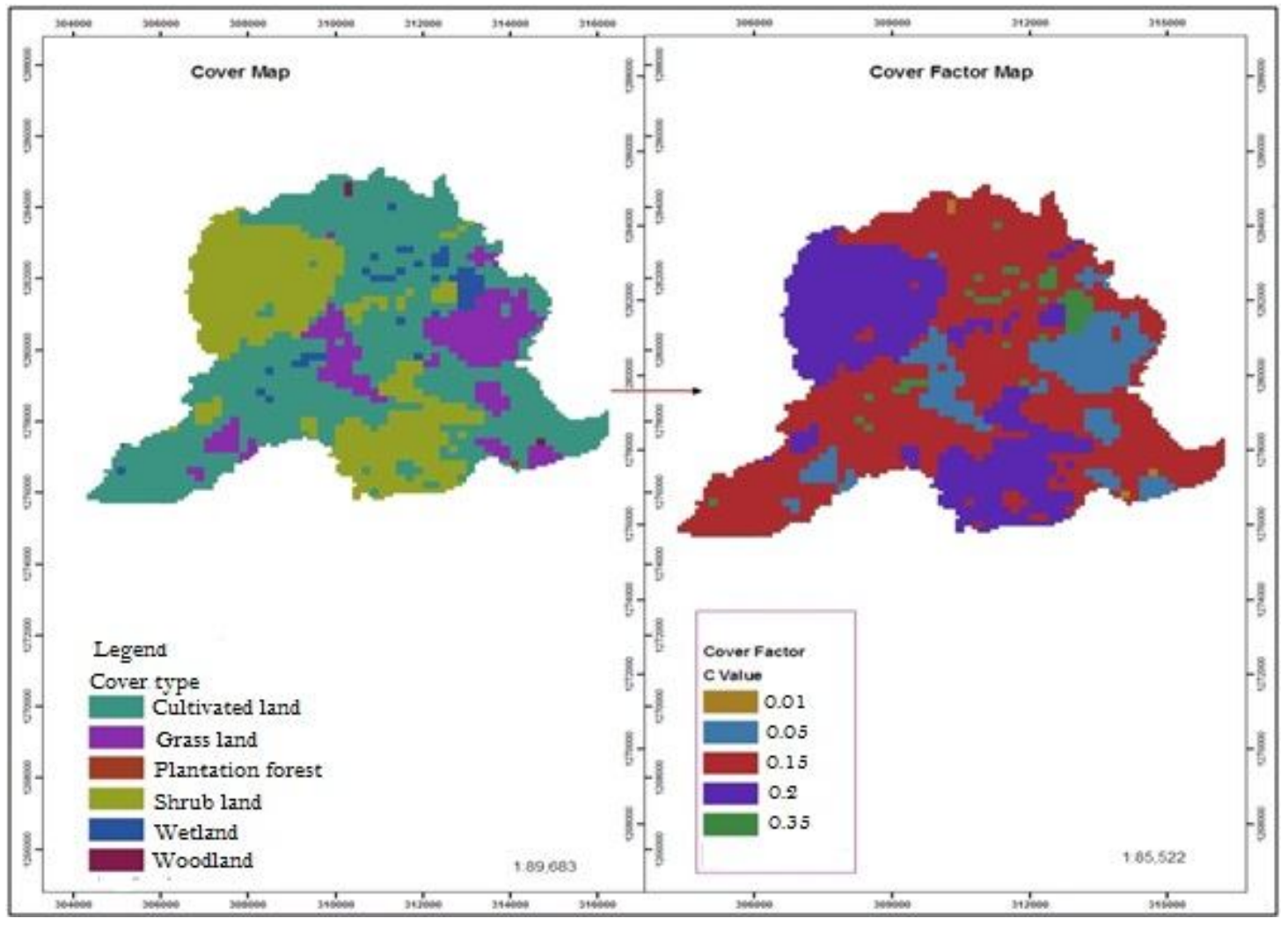

Fig. 7. Derivation of cover factor from cover type

\section{Management practice factor ( $P$ value)}

The conservation practices factor ( $p$-values) reflects the effects of practices that will reduce the amount and rate of the water runoff and thus reduce the amount of erosion. In the study area, there is only a small area that has been treated with terracing through the agricultural extension programme of the government and these are poorly maintained as implementation was performed without participation of the local people. As data were lacking on permanent management factors and there were no management practices, the P-values suggested in Bewket and Teferi (2009) were used. Thus, the agricultural lands were classified into six slope categories and assigned P-values while all nonagricultural lands were assigned a P-value of 1.00 (Table 2 and Fig. 7).

Table 2. Land management factor $(\mathrm{P})$ values

\begin{tabular}{lccc}
\hline Land use type & Slope (\%) & Area (ha) & P-Factor \\
\hline Cultivated Land & $0-5$ & 3198.13 & 0.1 \\
& $5-10$ & 225.73 & 0.12 \\
& $10-20$ & 96.58 & 0.14 \\
& $20-30$ & 29.22 & 0.19 \\
& $30-50$ & 13.17 & 0.25 \\
& $50-100$ & 0 & 0.33 \\
\hline Other land use & All & 2860.72 & 1
\end{tabular}




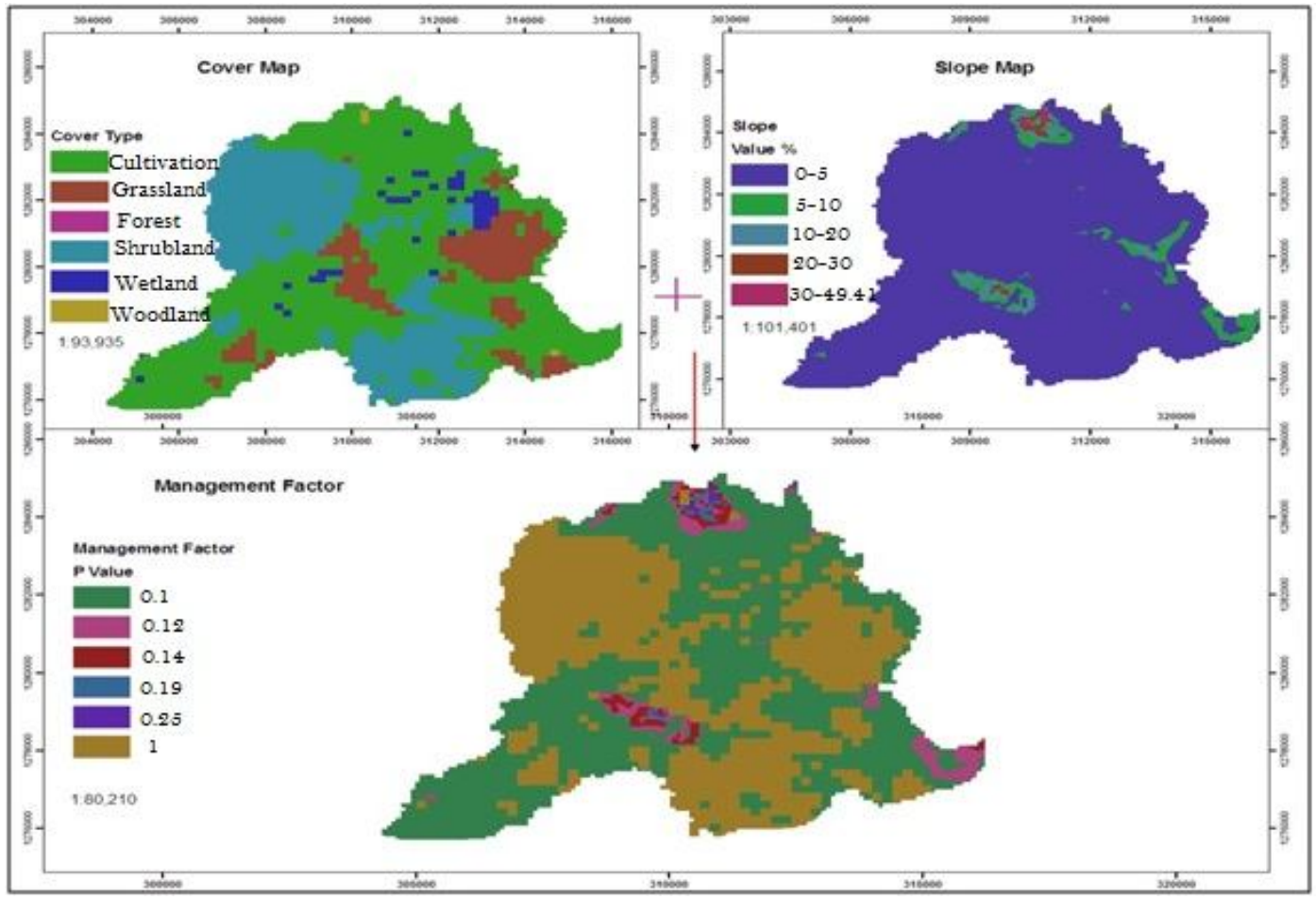

Fig. 8. Derivative of management factor from land cover and slope

Soil loss estimation and prioritization for soil conservation planning

The Revised Universal Soil Loss Equation (RUSLE) has been used widely all over the world (Mellerowicz et al., 1994) including Ethiopia (Kaltenrieder, 2007; Bewket and Teferi, 2009) because of its simplicity and limited data requirement. The advent of geographical information system (GIS) technology has allowed the equation to be used in a spatially distributed manner because each cell in a raster image comes to represent a field-level unit. Even though the equation was originally meant for predicting soil erosion at the field scale, its use for large areas in a GIS platform has produced satisfactory results (Mellerowicz et al., 1994). By delineation of micro-watersheds as erosion prone areas according to the severity level of soil loss, priority is given for a targeted and cost-effective conservation planning (Kaltenrieder, 2007).
Based on the analysis, about $92.31 \%$ (5914.34 ha) of the watershed was categorized none to slight class which under SLT values ranging from 5 to 11 tons ha- ${ }^{-1}$ year-1 (Renard et al., 1996). The remaining $7.68 \%$ (492.21 ha) of land was classified under moderate to high class about several times the maximum tolerable soil loss (Table 3 and Fig. 8). The total and average amount of soil loss estimated by RUSLE from the entire Enfraz watershed was 30,836.41 tons year 1 and 4.81 tons ha $^{-1}$ year ${ }^{-1}$, respectively. The implication is the contribution of the implemented soil water conservation measures in decreasing the rate of soil erosion is encourageable as compared to the results related to high soil loss estimated in the past studies. However, the present value indicates still a need for cost-effective conservation planning (Kaltenrieder, 2007; Bewket and Teferi, 2009) that decreases the amount of soil loss in the watershed.

Table 3. Soil loss rating and soil conservation priority areas

\begin{tabular}{|c|c|c|c|c|c|c|}
\hline & \multicolumn{3}{|c|}{ Soil Loss Rating } & \multicolumn{2}{|c|}{ Area Coverage } & \multirow{2}{*}{$\begin{array}{l}\text { Priority for } \\
\text { Intervention }\end{array}$} \\
\hline Class & Ton ha-1 year-1 & $\mathrm{mm}$ year $^{-1}$ & Descriptions & ha & $\%$ & \\
\hline I & $0-5$ & $0-0.5$ & Non to slight & 4090.15 & 63.84 & 7 \\
\hline \multirow[t]{2}{*}{ II } & $5-15$ & $0.5-1$ & Non to slight & 1824.19 & 28.47 & 6 \\
\hline & \multicolumn{2}{|c|}{ Sub total } & & 5914.34 & 92.31 & \\
\hline III & $16-30$ & 1-2.5 & Moderate & 321.54 & 5.02 & 5 \\
\hline IV & $31-50$ & $2.5-4$ & Moderate & 67.89 & 1.06 & 4 \\
\hline V & $51-100$ & 4-6.5 & High & 41.78 & 0.65 & 3 \\
\hline VI & $101-200$ & $6.5-16.5$ & High & 14.30 & 0.22 & 2 \\
\hline \multirow[t]{2}{*}{ VII } & $>200$ & $16.5-25$ & Very high & 46.70 & 0.73 & 1 \\
\hline & \multicolumn{3}{|c|}{ Sub total } & 492.21 & 7.68 & \\
\hline
\end{tabular}




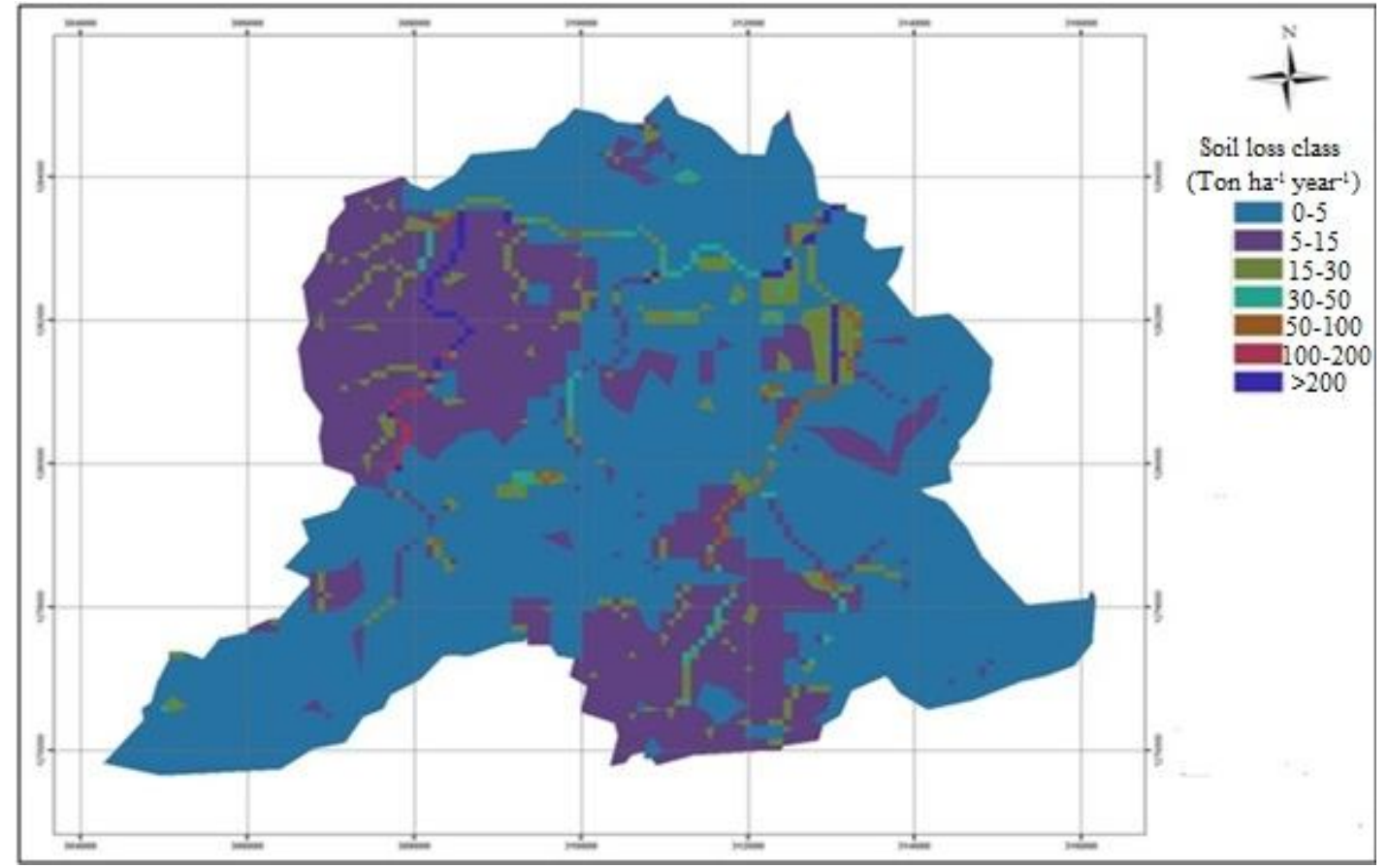

Fig. 9. Soil loss map of the watershed

\section{Conclusions and Recommendations}

The predicted amount of soil loss and its spatial distribution could facilitate comprehensive and sustainable land management through conservation planning for the watershed. Areas characterized by high to very high soil loss should be given special priority to reduce or control the rate of soil erosion by means of conservation planning. On the other hand, the management of moderate erosion hazard should be to protect them from further erosion, vegetation degradation and removal and stabilization through plantations. The study demonstrates that the RUSLE together with GIS and RS provides great advantage to estimate soil loss rate over areas. The parameter values of the factors are location specific and need to be calibrated to the specific area to enable reasonable prediction of the rate of soil loss.

\section{References}

Bewket, W. and Teferi, E. 2009. Assessment of soil erosion hazard and prioritization for treatment at the watershed level: case study in the Chemoga watershed, Blue Nile basin, Ethiopia, Land degradation \& development. Published online in Wiley Inter Science. pp. 1-14.

DSA (Development Studies Associates) and SCI (Shawel Consult International). 2006. Potential Survey, Identification of Opportunities and Preparations of Projects Profiles and Feasibility Studies. Addis Ababa, Ethiopia. p. 32.
FAO and UNEP. 1984. Provisional methodology for assessment and mapping of desertification. ISBN 925101442, FAO, Rome, Italy. p. 84.

FAO. 1984. Ethiopian Highland Reclamation Study (EHRS). Final Report, Rome. 1(2): 3746.

FAO. 1989. Reconnaissance physical land evaluation in Ethiopia. Addis Ababa, Ethiopia. p. 68.

Fikru, A. 1990. The role of land use planning in the improvement of natural resources management: In: National Conservation Strategy Conference. Ethiopia. 3: 5-12.

Gebreselasie, E.D. 1996. Soil erosion hazard assessment for land evaluation. Soil Conservation Research Program, MSc Thesis, University of Bern, Switzerland and the Ministry of Agriculture, Ethiopia. pp. 68-82.

Hellden, U. 1987. An assessment of woody biomass, community forests, land use and soil erosion in Ethiopia, Lund University Press, Sweden. p. 75.

Hurni, H. 1985. Erosion-productivityconservation systems in Ethiopia. pp. 654674. In: Proceedings $4^{\text {th }}$ International Conference on Soil Conservation, Maracay, Venezuela.

Hurni, H. 1993. Land degradation, famine, and land resource scenarios in Ethiopia. In: Pimentel D. (ed.) World soil erosion and conservation. Cambridge University Press. pp. 89-97. 
Kaltenrieder, J. 2007. Adaptation and Validation of the Universal Soil Loss Equation (USLE) for the Ethiopian-Eritrean Highlands. MSc Thesis, Centre for Development and Environment, Geographisches Institute, University of Berne, Switzerland. pp. 65-70.

Mellerowicz, K.T., Ress, H.W., Chow, T.L. and Ghanem, I. 1994. Soil conservation planning at the watershed level using the Universal Soil Loss Equation with GIS and microcomputer technologies: A case study. J. Soil Water Conserv. 49: 194-200.

Morgan, R.P.C. 1994. Soil Erosion and Conservation. Silsoe College, Cranfield University. UK. p. 36.

Morgan, R.P.C. 2005. Soil Erosion and Conservation ( $3^{\text {rd }}$ edn). Blackwell Science: Oxford. p. 320.

Renard, K.G., Foster, G.R., Weesies, G.A., McCool, D.K. and Yoder, D.C. 1996. Predicting Soil Erosion by Water: A Guide to Conservation Planning with the Revised
Universal Soil Loss Equation (RUSLE).Agric. Handbook 703. US Govt. Print Office, Washington, DC. p. 45.

Renard, K.G., Foster, G.R., Weesies, G.A., McCool, D.K. and Yoder, D.C. 1997. Predicting soil erosion by water - a guide to conservation planning with the Revised Universal Soil Loss Equation (RUSLE). Agriculture Handbook No. 703, USDA-ARS. p. 56.

Robert, P.S. and Hilborn, D. 2000. Factsheet: Universal Soil Loss Equation (USLE).Index No-572/ 751, Queen's printer for Ontario. pp. 35-36.

Sertu, S. 2000. Degraded Soil of Ethiopia and their management. pp. 68-69. In: Proceeding of FAO/ISCW expert consultation on management of degraded soils in Southern and East Africa. 2nd network meeting, 18-22 September 2000. Pretoria. 